placebo and monotherapies in functional residual capacity $(\mathrm{p}<$ $0.001)$ and residual volume $(\mathrm{p}<0.0001)$. Both FDCs were well tolerated; overall incidence of adverse events ranged between $36.0 \%(\mathrm{~T}+\mathrm{O} 2.5 / 5 \mu \mathrm{g})$ and $46.4 \%$ (placebo).

Conclusions Both FDC 24-hour time profiles showed clear and consistent increases in $\mathrm{FEV}_{1}$ compared to placebo and monotherapies, with a similar tolerability profile to $\mathrm{T}$.

\section{P259 TIOTROPIUM HANDIHALER® AND RESPIMAT® IN COPD: A SAFETY ANALYSIS ON POOLED DATA}

${ }^{1}$ DMG Halpin, ${ }^{2} \mathrm{R}$ Dahl, ${ }^{3} \mathrm{C}$ Hallmann, ${ }^{3} \mathrm{~L}$ Leimer, ${ }^{3} \mathrm{~A}$ Mueller, ${ }^{4} \mathrm{DP}$ Tashkin. ${ }^{1}$ Royal Devon and Exeter Hospital, Exeter, UK; ${ }^{2}$ Odense University Hospital, Odense, Denmark; ${ }^{3}$ Boehringer Ingelheim Pharma GmbH and Co. KG, Ingelheim, Germany; ${ }^{4}$ David Geffen School of Medicine UCLA, Los Angeles, California, USA

\subsection{6/thoraxjnl-2014-206260.387}

Rationale Tiotropium has been approved and marketed via HandiHaler ${ }^{\circledR}(18 \mu \mathrm{g}$ once daily [qd]) since 2002 and via Respimat ${ }^{\circledR}(5 \mu \mathrm{g} \mathrm{qd})$ since 2007 . The recent TIOSPIR ${ }^{\mathrm{TM}}$ (TIOtropium Safety and Performance In Respimat $\left.{ }^{\circledR}\right)$ study demonstrated that both products had comparable safety profiles; the objective of this analysis was to provide an updated safety evaluation of tiotropium in both formulations.

Methods Analysis of pooled adverse events (AEs) from randomised, double-blind, parallel-group, placebo-controlled clinical trials of $\geq 4$ weeks' duration where either tiotropium HandiHaler ${ }^{\circledR} 18 \mu \mathrm{g}$ or tiotropium Respimat ${ }^{\circledR} 5 \mu \mathrm{g}$ was indicated for chronic obstructive pulmonary disease (COPD). Rate ratios (RRs), incidence rates (IRs) and 95\% confidence intervals (CIs) were determined for HandiHaler ${ }^{\circledR}$ and Respimat ${ }^{\circledR}$ trials together and separately.

Results This analysis of 28 HandiHaler ${ }^{\circledR}$ and seven Respimat ${ }^{\circledR}$ studies provided 14,909 (12,469 and 2440 with HandiHaler ${ }^{\circledR}$ and Respimat $\AA^{\circ}$, respectively) patient-years' exposure to tiotropium. Mean age was 65 years and mean forced expiratory volume in 1 second was $1.16 \mathrm{~L}$ (41\% predicted). The risk (RR $[95 \% \mathrm{CI}])$ of AEs $(0.90[0.87,0.93])$ and serious AEs (0.94 $[0.89,0.99])$ was significantly lower with a numerically lower risk of death $(0.90[0.79,1.01])$ in the tiotropium group (pooled results) (Table). When separated by device, the risk of AEs and serious AEs remained lower in the tiotropium groups than placebo: RR 0.88 and 0.94 for HandiHaler ${ }^{\circledR}$ and 0.94 and 0.94 for Respimat ${ }^{\circledR}$ for AEs and serious AEs, respectively. Risks for cardiac events $(0.93[0.85,1.02])$ and major adverse cardiovascular events (MACE) $(0.87$ [0.75, 1.01]) were numerically lower and risk for respiratory, thoracic and mediastinal disorders $(0.76$ $[0.61,0.96])$ was significantly reduced in the tiotropium group. The typical anticholinergic effects of dry mouth (2.39 [2.01,

\begin{tabular}{|c|c|c|c|c|c|}
\hline & \multicolumn{2}{|c|}{ Placebo $(n=11,626)$} & \multicolumn{2}{|c|}{ Tiotropium $(n=12,929)$} & \multirow[t]{2}{*}{ RR $(95 \% \mathrm{Cl})$} \\
\hline & $\mathrm{n}(\%)$ & $\mathbb{I R}$ & $\mathrm{n}(\%)$ & IR & \\
\hline AEs & 7619 (65.5) & 152.85 & $8093(62.6)$ & 140.35 & $0.90(0.87,0.93)^{*}$ \\
\hline Serious AEs & $2654(22.8)$ & 23.08 & $2802(21.7)$ & 21.73 & $0.94(0.89,0.99)^{*}$ \\
\hline Fatal AEs & $523(4.5)$ & 3.71 & $515(4.0)$ & 3.27 & $0.90(0.79,1.01)$ \\
\hline MACE & $358(3.1)$ & 2.56 & $345(2.7)$ & 2.20 & $0.87(0.75,1.01)$ \\
\hline Fatal $\mathrm{MACE}^{\dagger}$ & $192(1.7)$ & 1.35 & $190(1.5)$ & 1.20 & $0.90(0.74,1.10)$ \\
\hline
\end{tabular}

2.84]), constipation (1.28 [1.06, 1.54]), intestinal obstruction (3.80 [1.42, 10.12]), dysuria (2.16 [1.31, 3.57]) and urinary retention $(1.93$ [1.21, 3.09]) were higher in the tiotropium group.

Conclusions The results from this safety review do not indicate an increased overall risk for fatal or cardiovascular events during tiotropium treatment, given via HandiHaler ${ }^{\circledR}$ or Respimat ${ }^{\circledR}$, in patients with COPD.

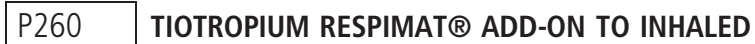 CORTICOSTEROIDS IMPROVES LUNG FUNCTION IN PATIENTS WITH SYMPTOMATIC MILD ASTHMA: RESULTS FROM A PHASE III TRIAL}

${ }^{1} \mathrm{P}$ Paggiaro, ${ }^{2} \mathrm{DMG}$ Halpin, ${ }^{3} \mathrm{R}$ Buhl, ${ }^{4} \mathrm{M}$ Engel, ${ }^{5} \mathrm{VB}$ Zubek, ${ }^{6} \mathrm{Z}$ Blahova, ${ }^{4} \mathrm{P}$ Moroni-Zentgraf, ${ }^{7}$ E Pizzichini. ${ }^{1}$ University of Pisa, Pisa, Italy; ${ }^{2}$ Royal Devon and Exeter Hospital, Exeter, UK; ${ }^{3}$ Mainz University Hospital, Mainz, Germany; ${ }^{4}$ Boehringer Ingelheim Pharma GmbH and Co. KG, Ingelheim Am Rhein, Germany; ${ }^{5}$ Boehringer Ingelheim Pharmaceuticals, Inc., Ridgefield, USA; ${ }^{6}$ Boehringer Ingelheim RCV GmbH and Co. KG, Vienna, Austria; ${ }^{7}$ NUPAIVA (Asthma Research Centre), Universidade Federal de Santa Catarina, Florianópolis, Santa Catarina, Brazil

\subsection{6/thoraxjnl-2014-206260.388}

Background Despite currently available therapies and detailed guidelines, many people with mild asthma remain symptomatic; it is important to establish the efficacy and safety of new treatments in this group.

Methods A Phase III, randomised, double-blind, parallel-group trial (GraziaTinA-asthma ${ }^{\circledR}$; NCT01316380) evaluated the efficacy and safety of once-daily tiotropium $5 \mu \mathrm{g}$ or $2.5 \mu \mathrm{g}$ versus placebo (all delivered via the Respimat ${ }^{\circledR}$ SoftMist ${ }^{\mathrm{TM}}$ inhaler) for 12 weeks in patients with symptomatic asthma on low-dose inhaled corticosteroids (200-400 $\mu \mathrm{g}$ budesonide or equivalent). The primary end point was peak forced expiratory volume in 1 second $\left(\mathrm{FEV}_{1}\right)$ within $3 \mathrm{~h}$ of dosing $(0-3 \mathrm{~h})$ response (change from baseline) at 12 weeks. Secondary end points were trough $\mathrm{FEV}_{1}, \mathrm{FEV}_{1}$ area under the curve $(\mathrm{AUC})_{(0-3 \mathrm{~h})}$ and peak expiratory flow responses (measured with the $\mathrm{AM} 2+{ }^{\circledR}$ device), and seven-question Asthma Control Questionnaire (ACQ-7) score.

Results Of 464 treated patients, 155 received tiotropium Respimat ${ }^{\circledR} 5 \mu \mathrm{g}, 154$ received tiotropium Respimat ${ }^{\circledR} 2.5 \mu \mathrm{g}$ and 155 received placebo Respimat ${ }^{\circledR}$. Both tiotropium Respimat ${ }^{\circledR}$ doses were superior to placebo Respimat ${ }^{\circledR}$ in peak $\mathrm{FEV}_{1(0-3 \mathrm{~h})}$ response (adjusted mean difference: $5 \mu \mathrm{g}, 128 \mathrm{~mL} ; 2.5 \mu \mathrm{g}, 159 \mathrm{~mL}$; both $\mathrm{p}<0.001$ ) and trough $\mathrm{FEV}_{1}$ response (adjusted mean difference: $5 \mu \mathrm{g}, 122 \mathrm{~mL}, \mathrm{p}=0.001 ; 2.5 \mu \mathrm{g}, 110 \mathrm{~mL}, \mathrm{p}=0.003) . \mathrm{FEV}_{1}$ $\mathrm{AUC}_{(0-3 \mathrm{~h})}$ response at each visit, versus placebo Respimat ${ }^{\circledR}$, significantly favoured tiotropium Respimat ${ }^{\circledR} 5 \mu \mathrm{g}(\mathrm{p}=0.009$ to $\mathrm{p}$ $<0.001$ ) and $2.5 \mu \mathrm{g}$ (all $\mathrm{p}<0.001$, except Day 1). Adjusted mean morning and evening peak expiratory flow responses, versus placebo Respimat ${ }^{\circledR}$, each week, all favoured tiotropium Respimat ${ }^{\circledR} 5 \mu \mathrm{g}$ (all $\mathrm{p}<0.001$ ) and $2.5 \mu \mathrm{g}$ (all $\mathrm{p}<0.003$ ). Adjusted mean ACQ-7 score was similar across all arms (tiotropium Respimat ${ }^{\circledR} 5 \mu \mathrm{g}, 1.391$; tiotropium Respimat ${ }^{\circledR} 2.5 \mu \mathrm{g}$, 1.438; placebo Respimat ${ }^{\circledR}, 1.377$ ). Adverse events were predominantly mild or moderate and were balanced between treatment groups.

Conclusion Tiotropium Respimat ${ }^{\circledR}$ was effective and well tolerated in patients with symptomatic mild asthma despite low-dose inhaled corticosteroid treatment. 